\title{
The Application of Teams Games Tournament (TGT) and Teaching Game for Understanding (TGfU) Learning Models on Learning Motivation and Volley Ball Passing Skills
}

\author{
Annisa Alifvia Artha ${ }^{\mathbf{1}}$, Abdul Rahman Syam T ${ }^{\mathbf{2}}$, Anung Priambodo ${ }^{\mathbf{3}}$ \\ 1,2,3 Magister of Sport Education, Universitas Negeri Surabaya, Surabaya, Indonesia \\ annisalifviartha45@gmail.com
}

\begin{abstract}
This study aim to examine the application of teams games tournament (TGT) and teaching games for understanding (TGfU) on learning motivation and volley ball passing skills students in grade 8th Muhammadiyah 1 Sidoarjo junior high school. This study uses a qualitative and quantitative approach to experiment research and non randomized control group pretest-posttest design to fix the population and sample. The qualitative approach of this study is filling out the learning motivation questionnaire, while the quantitative approach is conduct a volley ball passing skills test according to the norm. This approach is carried out befor and after treatment called pretest and posttest. The subjects were 87 students who devided into three groups in VIII-G, VIII-I, and VIII-J class. VIII-G class as a control group were not given a treatment, VIII-I class as the experimental group I (TGT), and VIII-J as the experimental group II (TGfU). Data were analized with descriptive statistics using the SPSS 22.0 program. Based on the data concluded that there was a significant increase in the experimental groups compared to the control group. It's show that learning motivation in experimental group I (TGT) is increase than experimental group II (TGfU) by 11,18\% for TGT and 5,76\% for TGfU. Volley ball passing skills test has increase by $19,56 \%$ in group I (TGT) and $15,48 \%$ in group II (TGfU). The result of this study is TGT and TGfU learning models can improve the level of learning motivation and volley ball passing skill.
\end{abstract}

Keywords

TGT; TGPU learning motivation; volley ball passing skills

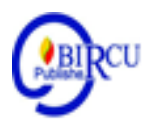

\section{Introduction}

Education is a fundamental effort to provide knowledge, perception, general and specifically skills, in order to develop individual skill and personalities (Sitorus \& Surya, 2017, p.17). Physical education is a process of education through physical activities (Mutohir, 2002, p.152). The limit given by Bucher (Sukintaka, 2004, p.16) physical education is part of total education to achieve goals through physical, mental, social and emotional development for the public through of physical activity.

The purpose of physical education oriented by a learning process for learn to move and learn trough motion. Hope students develops some aspects like fitness, movement, mental, critical thinking, social, self control, healthy life style, and clean environment by choosen and sistematic physic activities.

Rosdiani (2014, p.73) tell that learning is a process to help students to study better. The importance of PE in school will fulfill the needed and students movement skills. Student movement skills who unfulfilled, it caused some factors like the limited ability of PE teachers and supporting PE learning sources till ineffective learning (Mutohir, 2002, p.16). 
The result from Pill research (2011, p.120) stated that in traditional PE learning has suppressed the development of motor skills and fitness for games and sports. Faturrahman (2012, p.165) added that educators are required to be able to manage classrooms, implement learning methods, implement learning strategies, and manage attitudes and characteristics in managing learning to be effective, modify teaching materials properly, and improve students' abilities. Thus, teachers need to know the importance of applying appropriate learning models based on aspects needed by students and the available infrastructure.

The way when the teacher teach the students is a very important because this is one of the determinants of success in achieving learning goals. The learning model approach is an internal factor created to help the success of a learning using play models.

The importance of analyze the learning model at the beginning of the design can help students achieve their learning goals. Gill, Pizarro, Harvey, \& Villar (2017, p.2) convey the importance of analize learning models to increase student motivation when participating in PE. Cushion in Erliana (2019, p.57) adds the main key to the learning approach in playing sports is game sense.

In its activities, TGT applies tournament-based group games or competitions in deliver the material while TGfU applies modifications in the game. TGT gives more exploration space for students because in students will apply the knowledge and skills they have in the group. The application of TGfU teaches students to play better and enjoy PE compared to traditional learning methods (Robertson, 2016, p.3). TGfU model is dynamic so in its application, participants will get some mastery like mastery of knowledge, skills, strategies and tactics, rules of the game, and mastery in the context of the game (Samodra, 2015).

According to Uno (2016, p.3) motive is a driving force in a person to carry out certain activities to achieve a goal. Motivation can be interpreted as "A force or driving force to do something or display a certain behavior" (Gunarsa, 2008, p.47). Sage (in Gunarsa, 2008, p.47) states "Motivation can be defined simply as the direction and intensity of one's effort". Purwanto (2013, p.60) states that motivation is an absolute requirement for learning. Rea (2015, p.99) stated the ability to motivate someone is more important than added technical knowledge in sports. Deci \& Ryan (in Extremera, et al 2014, p.38) explain the theory of selfdetermination that there are three types of motivation including intrinsic, extrinsic and amotivational motivation.

Outdoor Learning Activity (OLA) is one of the best program ini Muhammadiyah 1 Sidoarjo JHS. This program made to train and looking for students skill into severals activity. For example social, cooking, spiritual, sains, art, music, craft, dance, and sport. Some activity occur on Monday and Tuesday like sains, art, music, craft and dance. Sport, social, spiritual and cooking occur on Friday at 07.30 till 08.30. Sport day is mini tournament which scheduled activities for each class. This tournament matches team sports so every class send some students to play. The delegation must wear sport uniform and ready to compete against another class. The boy versus the boy and the girl versus the girl, start from $7^{\text {th }}$ till $9^{\text {th }}$ grade.

Mutohir, et al (2013, p.1) added volleyball played by bouncing the ball from one member to another member into the opponent's area by pasing and smesh as a final settlement, the net with a predetermined height became the separator between the two teams.

\section{Research Method}

This study focuses on the problems about learning models, the first is to analyze an influence of the application of the TGT learning model on learning motivation and volley ball 
skills, the second to analyze an influence on the application of the TGfU learning on learning motivation and volley ball skills, and third, to find out the difference in on learning motivation and volley ball skills between the TGT learning model and the TGFU learning model. The types of variables used in this study are non randomized control group pretestposttest design.

Without knowing the right data collection techniques, researchers will not get data that is in accordance with established data standards (Sugiyono, 2013, p. 308). There are several things that are crucial in the selection of instruments according to Arikunto (2010, p. 203), namely the object of research, data sources, time and funds available, the number of researchers, and the techniques used to process data when it has been collected.

Three groups come from eigth grades, devided into the control group (VIII-G), the experimental group I (TGT) and the experimental group II (TGfU). All classess had a 1 week for pretest, 2 weeks for treatment and posttest for last week. The treatment were devide in three parts; an initial warm up (15 min), a main practice session (95 $\mathrm{min})$, and a final part (10 min). The initial part consisted mainly in warming up. The main session was volley ball passing learning TGT and TGfU modificated models. The final part consisted learning evaluated and flexibility excercises.

The questionnaire as a question to reveal factual data that the subject already knew was part of the interview and interpreted the questionnaire as a question that needed to be responded (Maksum, 2018, p.157). Learning quessionnaire model gived before and after the treatment takes place. The quessionnaire has 32 questions using likert scale.

Instrument to measure volleyball passing skill for 13-15 years old of age based on the National Physical and Recreation Center of the Ministry of National Education in 1999. Students must passing the ball till the ball passes the net and falls on the opponent's area. This passing is carried out for 1 minute and is calculated if the ball is in the area.

Source: National Physical and Recreation Center of the Ministry of National Education (Samodra, 2013, p.4)

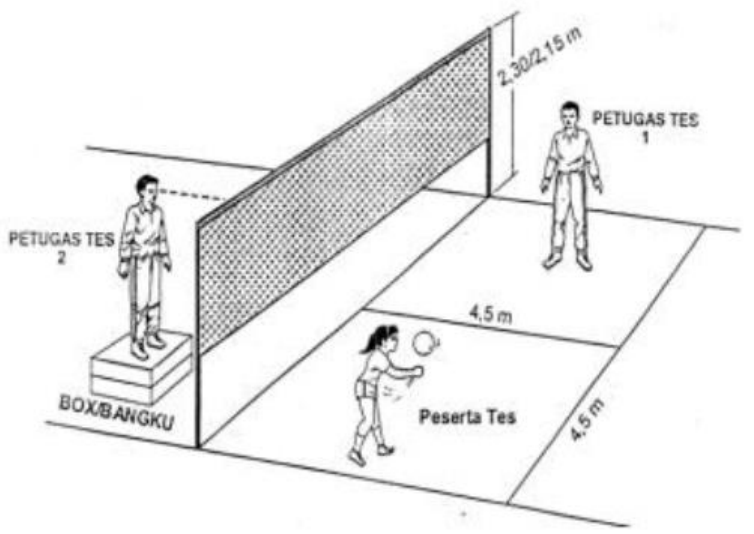

Descriptive statistical analyses were run on all variables. Validity and reliability test for the questionnaire. Sujarweni (2015, p.192) adds better when every question tested and compare with $\mathbf{r}_{(27)}$ and $\mathrm{r}_{\text {table }}$ $(0,05)$. Normality (Kolmogorov Smirnov) and homogenity (Levene) test for analize and make sure the data was normal and homogen, it can continued the next steps. Independet and paired sample t test used for making hypotheses. Independent sample $\mathrm{t}$ test used to calculate the average of two samples from different and unrelated groups, while paired t test used to calculate the average of two samples from related group.

\section{Discussion}

This research analized with SPSS 22.0 program. It's based on learning motivation questionnaire and the National Physical and Recreation Center of the Ministry of National Education in 1999 for volley ball passing skill. 
Validity test for 32 learning motivation question in this study show $r_{\text {tabel }}<r_{(30)}=0.301<$ 0.906 ( $\min )-0.915(\max )$ so 32 learning motivation question called valid. The next step was reliability test to fix the 32 question used is reliable, the cronbach's alpha show .912> score 0.60 , it's noted in tabel 1 , so the questionnaire can be used to this study.

Table 1. Learning motivation reliability test

Cronbach's Nof Items

Alpha

$\begin{array}{r}\text { Alpha } \\ \hline .912 \\ \hline\end{array}$

According a mean pre and post test percent, three groups show difference learning models and volley ball passing skill. Calculated with $\frac{3 K D}{3 \% \text { asttest }} \times 100 \%$, it's shows in table 2 and table 3.

Table 2. Descriptive statistic of learning motivation percent increasing

\begin{tabular}{ccccc}
\hline Group & $\begin{array}{c}\text { Mean } \\
\text { Pretest }\end{array}$ & $\begin{array}{c}\text { Mean } \\
\text { Posttest }\end{array}$ & MD & $\begin{array}{c}\text { Percent } \\
(\text { MD/Mposttest } \\
\text { x100\%) }\end{array}$ \\
\hline TGT & 104,90 & 118,10 & 13,2 & $11,18 \%$ \\
TGFU & 106,36 & 112,86 & 6,5 & $5,76 \%$ \\
Control & 108 & 108,38 & 0,38 & $0,35 \%$ \\
\hline
\end{tabular}

Table 3. Descriptive statistic of volley ball passing skill percent increasing

\begin{tabular}{ccccc}
\hline Group & $\begin{array}{c}\text { Mean } \\
\text { Pretest }\end{array}$ & $\begin{array}{c}\text { Mean } \\
\text { Posttest }\end{array}$ & $\begin{array}{c}\text { M } \\
\text { D }\end{array}$ & $\begin{array}{c}\text { Percent } \\
(\text { MD/Mposttest } \\
\text { x100\%) }\end{array}$ \\
\hline TGT & 8,10 & 10,07 & $\begin{array}{c}1,9 \\
7\end{array}$ & $19,56 \%$ \\
TGFU & 8,24 & 9,75 & $\begin{array}{c}1,5 \\
1\end{array}$ & $15,48 \%$ \\
$\begin{array}{c}\text { Contro } \\
1\end{array}$ & 8,96 & 9,86 & 0,9 & $9,12 \%$ \\
\hline
\end{tabular}

Table 2 indicate the TGT group score percent biggest than another groups, 11,18\% for TGT group, $5,76 \%$ for TGfU group and $0,35 \%$ for control group in learning motivation score. While table 3 indicate the TGT group score percent biggest than another groups, $19,56 \%$ for TGT group, $15,48 \%$ for TGfU group and 9,12\% for control group in volley ball passing skill score.

Before hypothesis test continued, normality and homogenity must be tested first over learning motivation and volley ball passing skill variabel. All variables calculated in normality and homogenity test are normal and homogen. It's noted in table 4 and table 5. 
Table 4. Normality test result

\begin{tabular}{cccccc}
\hline \multirow{2}{*}{ Variabel } & \multirow{2}{*}{ Test } & TG & TGf & \multirow{2}{*}{ KK } & \multirow{2}{*}{ Statu } \\
\cline { 3 - 5 } & & Sig & Sig & Sig & S \\
\hline \multirow{3}{*}{ Learning } & pretes & 0.14 & 0.20 & 0.20 & Norm \\
motivation & t & 5 & 0 & 0 & al \\
\cline { 2 - 5 } & postte & 0.20 & 0.20 & 0.20 & Norm \\
Volley & pretes & 0.13 & 0.10 & 0.05 & Norm \\
ball & t & 9 & 9 & 5 & al \\
passing & postte & 0.19 & 0.12 & 0.18 & Norm \\
skill & st & 6 & 8 & 5 & al \\
\hline
\end{tabular}

Table 5. Homogenity test result

\begin{tabular}{|c|c|c|c|}
\hline Variabel & Test & Sig & Status \\
\hline \multirow{4}{*}{$\begin{array}{l}\text { Learning } \\
\text { motivation }\end{array}$} & \multirow{2}{*}{ pretest } & 0.07 & Homoge \\
\hline & & 0 & $n$ \\
\hline & \multirow{2}{*}{ posttest } & 0.07 & Homoge \\
\hline & & 8 & $n$ \\
\hline \multirow{4}{*}{$\begin{array}{l}\text { Volley ball } \\
\text { passing skill }\end{array}$} & \multirow{2}{*}{ pretest } & 0.05 & Homoge \\
\hline & & 5 & $\mathrm{n}$ \\
\hline & \multirow{2}{*}{ posttest } & 0.18 & Homoge \\
\hline & & 5 & $\mathrm{n}$ \\
\hline
\end{tabular}

Normality and homogenity test called normal and homogen when P score (Sig > 0.05, it called abnormal and inhomogeneous when $\mathrm{P}$ score $<0.05$. Learning motivation questionnaire and volley ball passing skill can proceed to the next step.

Table 6 shows the descriptive statistic (independent sample t test) between TGT and TGfU class groups for learning motivation. Independent sample t test Sig.(2-tailed) score show .007 which more little than 0.05 , it's mean the experimental population are not identical or there were significant different between TGT model and TGfU models.

Table 6. Independent sample t test descriptive statistic for learning motivation.

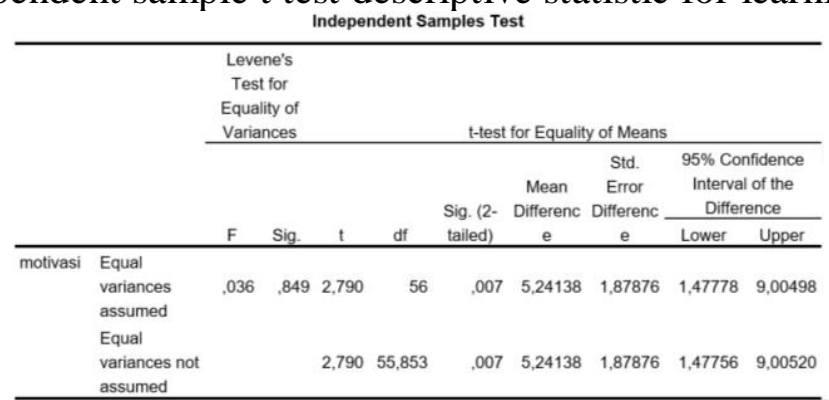

*Significant (2-tailed) at $\mathrm{t} \leq 0.05$ (independent $\mathrm{t}$ test)

The seventh table (Tabel 7) shows the descriptive statistic (independent sample t test) between TGT and TGfU class groups for volley ball passing skill. Independent sample t test Sig.(2-tailed) score show .829 which more than 0.05 , it's mean the experimental population are identical or there were no significant between TGT model and TGfU models. 
Table 7. Independent sample t test descriptive statistic for volley ball passing skill

\begin{tabular}{|c|c|c|c|c|c|c|c|c|c|c|}
\hline & & \multicolumn{4}{|c|}{$\begin{array}{l}\text { Levene's Test } \\
\text { for Equality of } \\
\text { Variances }\end{array}$} & \multicolumn{5}{|c|}{ t-test for Equality of Means } \\
\hline & & \multirow[b]{2}{*}{$\mathrm{F}$} & \multirow[b]{2}{*}{ Sig. } & \multirow[b]{2}{*}{$t$} & \multirow[b]{2}{*}{ df } & \multirow{2}{*}{$\begin{array}{l}\text { Sig. (2- } \\
\text { tailed) }\end{array}$} & \multirow{2}{*}{$\begin{array}{c}\text { Mean } \\
\text { Differen } \\
\text { ce } \\
\end{array}$} & \multirow{2}{*}{$\begin{array}{c}\text { Std. } \\
\text { Error } \\
\text { Differen } \\
\text { ce } \\
\end{array}$} & \multicolumn{2}{|c|}{$\begin{array}{c}95 \% \text { Confidence } \\
\text { Interval of the } \\
\text { Difference }\end{array}$} \\
\hline & & & & & & & & & Lower & Upper \\
\hline $\begin{array}{l}\text { ketram } \\
\text { pilan }\end{array}$ & $\begin{array}{l}\text { Equal } \\
\text { variances } \\
\text { assumed }\end{array}$ & .469 & ,496 & -217 & 56 & 829 & -37931 & 1,74862 & $-3,88222$ & 3,12360 \\
\hline & $\begin{array}{l}\text { Equal } \\
\text { variances } \\
\text { not assumed }\end{array}$ & & & -217 & 55,799 & ,829 & -37931 & 1,74862 & $-3,88249$ & 3,12387 \\
\hline
\end{tabular}

*Significant (2-tailed) at $\mathrm{t} \leq 0.05$ (independent $\mathrm{t}$ test)

Learning motivation descriptive statistics by paired t test result TGT group, TGfU group and control group show the significant different according Sig. (2-tailed) score.

All groups where significant different between pre- and post-test are noted in table 8 . Three scores were 0.000 for TGT group, 0.000 for TGfU group and 0.003 for control group which more little than 0.05 so there were significant different between pre- and post-test learning motivation in this study.

Table 8. Paired sample t test descriptive statistic for learning motivation

\begin{tabular}{|c|c|c|c|}
\hline Group & Pair & $t_{\text {hitung }}$ & $\begin{array}{c}\text { Sig. } \\
(2 \\
\text { tailed) } \\
\end{array}$ \\
\hline TGT & $\begin{array}{l}\text { Pretest- } \\
\text { posttes }\end{array}$ & -47.505 & 0.000 \\
\hline TGFU & $\begin{array}{l}\text { Pretest- } \\
\text { posttes }\end{array}$ & -7.558 & 0.000 \\
\hline Kontrol & $\begin{array}{l}\text { Pretest- } \\
\text { posttes }\end{array}$ & -3.266 & 0.003 \\
\hline
\end{tabular}

Table 9. Paired sample $t$ test descriptive statistic for volley ball passing skill

\begin{tabular}{|c|c|c|c|}
\hline Group & Pair & $t_{\text {hitung }}$ & $\begin{array}{c}\text { Sig. } \\
\text { (2 } \\
\text { Tailed) }\end{array}$ \\
\hline TGT & $\begin{array}{l}\text { Pretest- } \\
\text { posttes }\end{array}$ & -3.834 & 0.001 \\
\hline TGfU & $\begin{array}{l}\text { Pretest- } \\
\text { posttes }\end{array}$ & -5.483 & 0.000 \\
\hline Kontrol & $\begin{array}{l}\text { Pretest- } \\
\text { posttes }\end{array}$ & -1.967 & 0.059 \\
\hline
\end{tabular}

Volley ball passing skill descriptive statistics by paired t test result only experimental groups show the significant different according Sig. (2-tailed) score. It's noted in table 9. Experimental groups where significant different between pre- and post-test are 0.001 for TGT group and 0.000 for TGfU group. While the control group show 0.059 which more than 0.05 , it's make there is non-significant for control group in volley ball passing skill.

Increased motivation according to Weinberg \& Gould (2007, p.65) can be achieved in several ways. Theory by Weinberg \& Gould about increase motivation include understanding personal factors and individual situations, a person must have more than one reason to 
participate in sports including focus, environmental engineering, leaders influence motivation, use modification. The TGT group has $11,18 \%$ learning motivation increasing score while 19,56\% for volley ball passing skill score. This scores bigger than control group where $0,35 \%$ for motivation and 9,12\% for passing skill. The scores can caused from environmental engineering in PE learning. Environmental engineering can applied for modified PE learning to increase learning motivation and passing skill.

The TGfU group has 5,76\% learning motivation increasing score while $15,48 \%$ for volley ball passing skill score. This scores bigger than control group where $0,35 \%$ for motivation and $9,12 \%$ for passing skill. A theory by Mauldon \& Redfern (in Stolz \& Pill, 2014, p.38) a sports instructor should not rely on those who are experts in their fields, but have a new approach to teaching games that include three elements, namely team games so that a teaching based on channeling talent and concepts in the game.

Learning models expected give a positif effect like increasing students skill, self confident, become active students, understanding the sport theory, and more focus to get learning goal.

Independent sample $\mathrm{t}$ test shows that there are differences in learning motivation between TGT learning model and TGfU learning model. The results of tests on volleyball underpass skills show that there are no differences in skills between the TGT learning model groups and TGfU learning models.

In the paired sample $t$ test the TGT and TGfU groups showed differences in learning motivation after the learning model was applied in classroom (sig. 2 tailed score was 0,000 in the TGT group and 0,000 in the TGfU group). The difference was shown again in the skill of volley ball passing skill, the two experimental groups shows the sig. 2 tailed is smaller than the significant level of 0.05 (sig. 2 tailed value is 0.001 in the TGT group and 0.000 in the TGfU group) so in this case it can be concluded that the application of the TGT and TGfU learning models can increase learning motivation and volleyball passing students skills.

\section{Conclusion}

From data processing and data analysis result, TGT and TGfu learning models in groups give an influence on learning motivation and volley passing skill students eight grades in Muhammadiyah 1 Sidoarjo JHS. (1) TGT learning model have a significant influence on learning motivation and volley ball passing skills, (2) TGfU learning model have a significant influence too, (3) between TGT and TGfU, there is a difference in learning motivation, but not difference in students volley ball skill.

The difference seen from mean data. The learning models show that learning motivation in experimental group I (TGT) is increase than experimental group II (TGfU) by $11,18 \%$ for TGT and 5,76\% for TGfU while volley ball passing skills test has increase by $19,56 \%$ in group I (TGT) and $15,48 \%$ in group II (TGfU).

\section{References}

Arikunto, Suharsimi. 2010. Prosedur Penelitian : Suatu Pendekatan Praktik. Jakarta : Rineka Cipta.

Erliana, Mita. 2019. "Pengaruh Pembelajaran Model Bermain terhadap Keterampilan pasing Bawah Bola Voli Mini”. Jurnal Multilateral. Vol 13. No 1. 
Extremera, A. B., López, M. G., Gallegos, A. Granero., \& Abraldes, A. J. 2014. "Motivation, motivational climate and importance of Physical Education". Procedia-Social and Behavioral Sciences, 132, 37-42.

Faturrahman, dkk. 2012. Pengantar Pendidikan. Jakarta: Prestasi Pustaka Publisher.

Gill, A., Pizarro, A. P., Harvey, S., Villar, F. D. 2017. "Impact of a Hybrid TGfU-Sport Education Unit on Student Motivation in Physical Education". PloS ONE, 12(6):1-11. doi: 10.1371/journal.pone.0179876.

Mutohir, T. C. 2002. Gagasan-gagasan tentang Pendidikan Jasmani dan Olahraga. Surabaya: Unesa University Press.

Mutohir, T. C., Muhyi, M., Junaidi, S., Ahmad, L., Bekti, A.R., Rusdiyanto., Primiatiningsih. (2013). Permainan Bola Voli: Konsep, Teknik, Strategi dan Modifikasi. Surabaya: Graha Pustaka Media Utama.

Pill, Shane. 2011. "Teacher Engagement with Teaching Games for Understanding - Game Sense in Physical Education”. Journal of Physical Education and Sport, 11(2):115-123.

Purwanto, N. M., 2013. Psikologi Pendidikan. Bandung: Rosda.

Rea, Simon. 2015. Sport Sciene: A complete introduction. UK : John Murray Learning.

Robertson, Scot. 2016. "Investigation the Relationship between Teaching Games for Understanding and High School Physical Education Students' Enjoyment, SelfEfficacy, and Intentions to Enroll". Ontario: Brock University.

Rosdiani, Dini. 2014. Perencanaan Pembelajaran dalam Pendidikan Jasmani dan Kesehatan. Bandung: Alfabeta.

Samodra, Juni Y.Touvan. 2013. Model Pembelajaran Taktikal Game dalam Pendidikan Jasmani. Bandung: CV. Bintang Warli Artika.

Sitorus, N. E \& Surya, Edi. 2017. "The Influence of Teams Games Tournament Cooperative Learning Model on Students' Creativity Learning Mathematics". International Journal of Sciences: Basic and Applied Research. 34(1): 16-24.

Stolz, Steven., Pill, Shane. 2014. "Teaching Games and Sport for Understanding: Exploring and Reconsidering Its Relevance in Physical Education". European Physical Education Review. 20(1):36-57. doi: 10.1177/1356336X13496001.

Sugiyono. 2013. Metode Penelitian Pendidikan : Pendekatan Kuantitatif, Kualitatif, dan $R$ \& $D$. Bandung : Alfabeta.

Sujarweni, V. Wiratna. 2015. SPSS untuk Penelitian. Yogyakarta : Pustaka Baru Press.

Sukintaka. 2004. Teori Pendidikan Jasmani. Bandung: Nuansa.

Uno, B., Hamzah. 2016. Teori Motivasi dan Pengukurannya : Analisis di Bidang Pendidikan. Jakarta : Bumi Aksara.

Weinberg, Robert S; Gould, Daniel. 2007. Foundations of Sport and Exercise Psychology. Human Kinetics. 